5. Розеншильд К.К. Аффектов теория// Музыкальная энциклопедия. Гл. ред. Ю.В.Келдыш.т.1.М.:Советская энциелопедия,1973. С.256-260.

6. Фан Минцзе. Техника bel canto как предмет теоретического изучения в Китае: история и современность// Colloquium-journal.Warszawa Poland. 2019.№16(40). C.23-27

7. Федосеев И.С. Оперы Г.Ф.Генделя и Королевская академия музыки в Лондоне (1720-1728). СПб.: Сударыня,1996. 160с.

8. Чайковский П.И. Музыкально-критические статьи. М.:Гос.муз.изд.во,1953. 436с.

\title{
Shi Yawen \\ Musical intonation as a problem of interpretation in the aspect of modern Chinese pianism
}

Russian State Pedagogical University named after A.I. Herzen

(Russia, St. Petersburg)

doi: $10.18411 / s r-10-08-2020-32$

idsp: sciencerussia-10-08-2020-32

\section{Abstract}

The article considers the term "intonation" from the point of view of the theory and practice of modern performing art on the piano. As an example, the analysis of interpretations of prominent Chinese pianists Fu Tsung and Li Yundi is given. The purpose of the article is to delve into the concept "intonation on the piano", and correlate it with representatives of the Chinese piano elite. The article draws attention to the difference between the speech structures of Slavic and Chinese languages, which is directly related to the concept "intonation". In Russian and Chinese musicology, this problem is touched upon for the first time.

Keyword. Piano, intonation, expressiveness, speech, music, competition, pianism.

\section{Paper}

Introduction. The term "musical intonation" has a multifaceted meaning in the theory and practice of musical art, and quite a long history of its development and comprehension. As a theoretical and practical concept, it partly appears in times of antiquity in works of Aristotle, Dionysius Halicarnassus, and then in Middle Ages in treatises of John Cotton, and in the Renaissance in works of Vincenzo Galilei. In the Age of Enlightenment, this term was used by French Lumières - Jean Jacques Rousseau, Denis Diderot, and by composers of that time period - Andre Gretry, Christoph Willibald Gluck. In the same period, in the XVIII century, the French Lumières first formulated the idea of correlation between "intonation of melody" and "intonation of speech", i.e. the singing voice "imitates various expressions of the speaking voice, animated by feelings" (J.J. Rousseau). Later on, the works and statements of such Russian critics and composers of the XIX century, as A.S. Dargomyzhsky, A.S. Serov, M.P. Mussorgsky, V.V. Stasov, P.I. Tchaikovsky, N.A. Rimsky-Korsakov, were of great importance for development of the musical intonation theory. In the XX-XXI centuries, in Russian musicology, the term "musical intonation" is a widely branched theory used in many areas of musical art. In Chinese musicological literature, this problem has not yet been developed.

The purpose of this article is to delve into the concept "prosodic intonation on the piano" and correlate it with representatives of the Chinese piano elite of our time period. What is the prosodic language of Chinese pianists when playing the piano, and is it different from the European one?

Literature Review. We refer to the opinion of Russian authoritative scientists. Thus, the famous Russian musicologist A.N. Sokhor (1924-1977) pointed out, "Musical intonation is related in origin and in many ways similar to the speech one, understood as changes in sounding ("tone") of the voice and, above all, in the pitch of the voice ("speech melody") [8, 
c.555]. Intonation in music is similar to intonation of speech (if you mean the pitch of the latter) in its meaning function (although in speech the main carrier of meaning is a word). The founder of the intonation theory in Russian music B.V. Asafyev (1884-1949) wrote about the main quality of intonation in the book "Musical Form as a Process": "Singers and instrumentalists instinctively, through the practice of performance and properties of the voice and instruments, feel the value of intonation... to keep the tone, to have the tone is not a whim. The cornerstone of music is to be within the tone, in this system of interface of sounds. In music, to be within the tone, i.e. to properly intonate, is the law of intonation as utterance of thought and feeling in verbal or musical speech. So, this quality of music is not accidental, but makes it the art of communication; and the more meaningful and intellectual the music, the stricter its intonation should be, because each given stage of musical intonation as a sphere of composer's thinking, becomes more complicated and more precise with regard to receptivity of thoughts and emotional tone"[1, p.216-217]. Generalizing meaning at the time had the work of V.V. Vanslov "The Concept of Intonation in Modern Musicology"[2]; the book of N.G. Shakhnazarova (1924-2016) "Prosodic "Dictionary" and the Problem of Ethnicity in Music" showed the problem of musical intonation from the point of view of public consciousness and national characteristics of intonation as a necessary component[10]. In the article "Chinese pianists-performers of works by Frederick Chopin in the musical space of Eurasia in the aspect of prosodic sounding", for the first time in Russian and Chinese musicology, its authors T.P. Samsonova and Shi Yawen raised the issue of piano intonation by famous Chinese musicians, and of the specifics of their musical interpretation [11, p.117122]. This article - "Musical intonation as a problem of interpretation in the aspect of modern Chinese pianism" - develops the idea of specific features of piano intonation specifically among Chinese pianists. The article analyzes interpretations of famous Chinese pianists $\mathrm{Fu}$ Tsung and Li Yundi.

Methodology. In the article, methods of historical, source studies, musical-theoretical and comparative analysis are applied. The method of active illustration is also used, with involvement of visual music material and video sound from the Internet (YouTube) [13].

Main part. As analytical reflection, we will focus on the winners of the International Frederick Chopin Piano Competition in Warsaw (Poland) - Fu Tsung (born in1934), the winner of the Chopin competition in 1955, and Li Yundi (born in1982), the winner of the I prize of the Chopin competition in 2000. Why did we focus on the Chopin international competition? According to the requirements of the International Frederic Chopin Piano Competition, the performers on all tours play Chopin. The problem of intonation generally is quite complex, and performance and intonation of Slavic music, - it is the area of music where Chopin's music belongs to, - is particularly difficult for Chinese musicians. The roots of this problem lie in the mental speech structures, the "irreducibility" of languages of Asia and Europe, differences in internal intonation of Slavic and Asian speech. Therefore, reproaches to Chinese pianists in excessive mechanistic technicality, in absence of "live" intonation, are quite frequent. As many researchers (Yu. Kremlev, A. Solovtsov, Ya. Milstein) noted, Chopin's music is deeply national, it absorbed all subtle nuances of Slavic song and dance folklore. In a well-known monograph devoted to Chopin's works, Yu. Kremlev wrote, "all works are national... Chopin was a folk poet not only because he wrote mazurkas and Polish; it is not the case of the form but of the essence, of the spirit of the works... Chopin is the same folk poet-musician in his nocturnes and ballads..." [4,p.333]. Another term, difficult to translate into verbal language, which Chopin left for future generations, is tempo rubato, without which it is impossible to do when performing Chopin's music. This is a special sphere of performance freedom, where the pianist's measure of taste, general and pianistic culture very vividly manifest themselves. These are the complex problems that arise for Chinese pianists when performing Chopin's music. Not everybody copes with them. In this article we will focus on the Chinese winners of the Chopin competition, the best 
representatives of the modern piano art of China, who have absorbed niceties of intonation performance and entry into the world of Chopin's music.

Chinese pianist $\mathrm{Fu}$ Tsung received the title of laureate at the V International Frederick Chopin Piano Competition in 1955. He was the first Chinese pianist to reach the international level. Fu Tsung was born in Shanghai in 1934. His father, Fu Le, was a famous Chinese art scholar and translator. As a child, he studied under the Italian pianist Mario Pacci, who studied under Sgambatti, F. Liszt's pupil, and the Soviet pianist Ada Bronstein. Fu Tsung started seriously to go in for music when he was 17 . At the age of 18, he gave his first concert. At the IV World Youth and Students Festival in Romania in 1953, Fu Tsung won the third prize. Since $1954 \mathrm{Fu}$ Tsung studied the art of piano under Zbigniew Drzewiecki, Professor of Warsaw Institute of Music. After six months of studying under the Polish Professor, Fu Tsung took part in the International Frederick Chopin Piano Competition in Warsaw. At this competition, Fu Tsung won the third prize and the honorary "Prize for the best performance of Chopin's Mazurka".

Due to the difficult domestic political life in China, Fu Tsung lived in England from 1959 to 1979. Twenty years away from his homeland remained forever in Fu Tsung's soul. On the spiritual relationship with Chopin, Fu Tsung said, "My fate resembles Chopin's, and in spirit Chopin is me. For me, to play his music is as natural as to speak" [3,p.126]. The pianist points out, "The most important thing in Chopin's music is the sense of homeland, endless bitterness, sadness, eternal anguish because of hopelessness of the situation... these feelings completely filled his music''[ Ibid,p.40]. These words speak for many things in Fu Tsung's pianistic appearance: deep understanding of Chopin's music and style, the pianist's thin emotional feeling.

$\mathrm{Fu}$ Tsung's general performance concept concerning Frederick Chopin's music and performance of the composer's works is rather meaningful, "Music is a limitless world. Chopin's musical harmony is very rich, and the level of polyphony is very high. In his music, one can find the art of sketching the landscape of China, especially landscape painting by Huang Binhuang (a modern artist of China); these sketches consciously and naturally permeate his works..., ordinary people playing Chopin, hear only the melody. Chopin's melodies are beautiful, but, apart from the beauty of the melody, people often neglect other musical components. In the upper layers of his music... there are magnificent touches, while in the lower voices there are also many lines that carry a myriad of nuances. In addition, Chopin's music has the beauty of harmony. In contrast to the music, where the right hand plays the melody, and the left hand accompanies, Chopin's music has no accompaniment, everything is fully expressive and vividly meaningful..."

"Why do people consider Chopin a 'piano poet'? His music is as close to poetry as possible! About folklore origins, people say, that during performance of Chopin's music, songs are required, and, typically, before a song dances are required; his music entirely manifested itself in folk dances, everything speaks for this! Even in his ballads, there are traces of mazurka and waltz. In Concerto № 1, the first part is followed by the Polish dance is reflected, and in the orchestral Solo, there is mazurka".

Continuing his thoughts on speech intonation in Chopin's music, Fu Tsung points out, "Chopin's music is so close to poetry that he seems to be talking to you" [9, p.32]." As an example, Fu Tsung cites the Nocturne E-dur op.62, at the first contact with which, the Chinese pianist recalls the poetic lines, "My tearful eyes seek an answer from the flowers, but those are silent. I see the red flowers bloom on the swings (the lines from Ouyang Xiu's poem "Butterflies in Love with Flowers") [9, p.40]. After all, how real is this red color! Each time, when playing this work, there is a feeling as "the tearful eyes seek an answer from the flowers, but those are silent. Chopin's music makes everyone feel a conversation with him, with poetry!" $[9, \mathrm{p} .84]$. 
According to Fu Tsung, Chopin's music is very close to the Chinese culture in its sophistication and refinement, in deep feelings of his native land, in love with the surrounding nature. Fu Tsung observes, "There are fewer and fewer people who feel Chopin well, there are very few of them around the world, because there are not enough poems in simple language, and the same deep feeling that Chopin has..." [9,p.128].

For twenty years (60s and 70s), Fu Tsung gave two thousand four hundred solo concerts, performed together with many famous performers, such as Ye. Menuhin, D. Barenboim, Chun Kunha. He recorded 50 records. Fu Tsung was one of the jury members of the Chopin international competition, the International Empress Dowager of Belgium Music Competition, as well as many music competitions in Norway, Italy, Switzerland, Portugal, Southeast Asian countries and other countries of the world. Fu Tsung performed solo concerts in Europe, America, the Middle East, Southeast Asia, Japan and Oceania. With his hard work, he won the title of "strong master". English newspaper "The Times" called him "the greatest Chinese musician in the modern world".

In 1976, Fu Tsung gave a concert at the Central Conservatory of China. Then, almost every year, when he came to his homeland, he gave concerts or lectures on music. He visited Beijing, Shanghai, Sian, Chengdu, Kunming and other cities in China. Fu Tsung lectured on works of Chopin, Mozart, Debussy, and gave recitals from these authors' works. Fu Tsung performed together with the Central Orchestra of China, playing Beethoven's concertos. In addition, Fu Tsung was the conductor of many symphony concerts given by students of the Beijing Central Conservatory. Fu Tsung helped establish the high school chamber music orchestra at the Beijing Central Conservatory.

$\mathrm{Fu}$ Tsung became a world-class pianist, the first Chinese pianist to win the title of laureate at the prestigious Frederick Chopin competition in 1955. Fu Tsung's creative personality is filled with love for music and pedagogy; he raised a whole generation of young musicians-pianists.

Li Yundi (born in 1982) is the youngest representative of the brilliant galaxy of Chinese pianists-competitors of the late XX century. Li Yundi is the only Chinese pianist educated in China. He became the youngest winner of the Frederick Chopin International Piano Competition in 2000, and the first in fifteen years to be awarded the highest award of the Frederick Chopin competition. Meanwhile, his birth in the city of Chongqing, Sichuan province, in the family of an ordinary worker, did not foretell such a brilliant rise in piano career. When he was 3, the boy was surprised at the accordion, and he learned to play it; at the age of 5, he became a winner at the children's accordion competition "Hongshenbei"; and only when he was 7 , he chose for himself the final instrument - the piano. In his music education, two people played an exceptional role. They were the famous Chinese Professor Dan Zhaoyi, and Li Yundi's mother - Zhang Xiaolu, who constantly accompanied her son to various competitions. There were many competitions, and everywhere Li Yundi was noticed: in 1995, entering the first class, Li Yundi first participated in the International I. Stravinsky Youth Piano Competition in the United States, taking the third prize there; in June 1997, he took won in the highest group at the I Piano Competition held by the Hong Kong Piano Association. There, Li Yundi performed the piano concerto "Huanghe" ("Yellow River") by the composer Xian Xinghai; in 1998, Li Yundi won the third place at the International Competition in the USA, which was held by the University of Missouri (Missouri Southern State University); in 1999, he received the third prize at the International F. Liszt Piano Competition in Utrecht (Netherlands); in December 1999, Li Yundi won the third place at the II International Piano Competition in Beijing. In 2000 he won the XIV International Chopin Piano Competition in Warsaw (Poland).

Such intensive participation in competitions testifies to outstanding diligence, physical and psychological endurance, will to win and the high level of the general and pianistic culture. 
Li Yundi's path to success was paved by the remarkable educator Professor Dan Zhaoyi. He gave his pupil his high ideals for musical art: sensitive intonation of sound, understanding of the meaning and the form of a musical work, niceties of coloristic sensations of the piano. When working on the piano technique, Dan Zhaoyi demanded strength, flexibility and accuracy of each finger, even performing etudes, he achieved expressive intonation and musicality of phrasing. Dan Zhaoyi's main method of work was an individual approach to the student. When little Li Yundi came to study under Professor Dan Zhaoyi, the boy had short fingers and a small hand, while the Professor told the talented student that "it's nothing, the main thing is music, and as for the hands and fingers, they will definitely grow" [5, p. 8-10]. Since his childhood, Li Yundi was never afraid of the stage, loved to perform. His first teacher recalled, "All the vitality and the spirit of this kid manifested themselves as soon as he went on stage. His eyes were particularly round and his pupils dilated, small dimples appearing on his face when he smiled. When he played, his face became extremely expressive, and this state of mind instantly captured the attention of the audience" [5, p.8688].

By the age of 15, Li Yundi had formed a character, his way of thinking, his attitude to music and the works performed. Professor Dan Zhaoyi told about his student, "Yundi has nice ear and musical intuition; besides, he is completely engrossed by it, he has mastered the technique well, is endowed with the rich musical flair, he is both very passionate and internally restrained, which makes his game attractive and exciting" [5,p.8].

After winning the Frederick Chopin Competition, Li Yundi mastered his skills in Germany, at the Hanover High School of Music and Theater, under pianist Ari Vardi. Li Yundi became a "chopinist" in his calling and piano style. In Europe, he was recognized as "the successor of the romantics school" and "the king of the piano".

Actively cooperating with the firm "Deutshe Grammophon", Li Yundi released a lot of records devoted mainly to Chopin's works. Currently, due to high-quality recordings, you can get thoroughly acquainted with Li Yundi's works in the Internet (YouTube). Nice footage gives the opportunity to observe the pianist at close range, to read his body language, to follow each of his finger's movement. Small, but very flexible and dexterous hands of Li Yundi do not know technical barriers: the pianist's chord, octave, "openwork" small technique is impeccable. One cannot but note that Li Yundi is fluent in "singing on the piano". It is known that Chopin advised his students to listen to the great singers of his time: Maria Malibran, Giudita Pasta, Antonio Tamburini, and learn from them singing bel canto. In this sense, Li Yundi is a successor of the tradition of "singing on the piano", which goes back to Chopin himself.

We know Chopin exclusively as a piano composer, as "a piano poet", who created his own unique "image of the piano". Chopin pushed the genre diversity of piano music, and this world turned into the Universe of diverse musical forms and romantic feelings, passions, hopes, memories, aspirations for an unattainable ideal, poetic and sublime expression of human emotion in musical sounds.

The world of Chopin's music is huge: piano concertos (2), nocturnes (21), mazurkas (56), polonaises (16) waltzes (14), piano sonatas (3), preludes (26), impromptu (4), etudes (27), scherzos (24), ballads (4). As a true "chopinist", Li Yundi has in his performer's baggage almost all species of the genre variety of Chopin's music, and it's not just a case of the number of works played at concerts, but of deep comprehension of Chopin's music, to identify the characteristics of each work, careful attitude to the text, to every tone in the phrase, in the graceful manner of tempo rubato, never turning into a pathetic fake style of playing. Li Yundi managed to deeply grasp the essence of Chopin's music, so the audience so enthusiastically accepts the pianist, finding in his interpretations the joy of "recognizing" a pure romantic image. Performing Chopin's music, Li Yundi is diverse and deep, tragic and tender, extremely masterful and demonic, he is passionate and restrained. It is the diverse 
palette of Li Yundi's performing style that we wanted to emphasize in the works that we have chosen for the performing analysis.

Sonata in B flat minor, Op.35[12],[13]. Sonata in B flat minor, Op.35, in four parts, is one of the greatest and most dramatic works of the Polish composer. When interpreting this work, the pianist Li Yundi appears to be a master of the large form. As an architect, he built an impeccable musical "building", not one iota deviating from Chopin's design. All four parts are listened to with intense attention, "in one breath". The important role in this is played by the tempo of the work itself, chosen by the performer, dynamic and excited, powerful dynamics, contrast of images - from the intermittent excited speech of the main part, to the courageous, singing lyrics of the side part. The pianist powerfully and solemnly plays the opening bars, which are suddenly replaced by the main theme of the agitato, which swirls in continuous "stream". The Polish researcher of Chopin's work J. Ivashkevich compared this theme with the bloody ballad "The Forest King" by F. Schubert, devoid of any sentimentalism" [4,p.556].

The episode of the side part in D flat major sounds poetic and enlightened. Li Yundi's chord texture sounds surprisingly soft, "singing" of the upper voice is answered by bass melodies, very relief, timbre interestingly painted, in Li Yundi's performance.

With each subsequent performance of the theme, Li Yundi fills it with emotion, achieving self-forgetful delight at the moment of culmination. Here we would like to draw attention to the skill with which the pianist compacts and melodizes the entire texture, and, in particular, the bass voice, which is entrusted with maintaining its own melodic line.

The second part of the Sonata is a scherzo (E flat minor). This is the realm of evil, pounding rhythm, its dark energy. The scherzo culmination in Li Yundi's performance sounds bright, powerful and tragic. The video makes it possible to see the amazing flexibility of his hands, refinement of the piano apparatus. In this culmination the destiny of the further tragic course of the musical "action" becomes apparent. Here, Li Yundi uses interesting pedal effects.

The middle part of the scherzo (in $\mathrm{G}$ flat major) begins without any transition. But this is a very different sphere - a quiet slow waltz. Here, as in the future concepts of Tchaikovsky's symphonies, the waltz is connected with the beauty that life brought: the beauty of love, friendship, the poetized habitual-native life, everything that helped to forget, to suspend anxious thoughts at least for a while.

The third part of the Sonata is "Funeral March", with the melody of the middle part, unusual in its beauty. It is a dramatic center of the Sonata in B flat minor. Li Yundi plays this music soulfully, without false pathos. In his hands it is both solemn and restrained. With its "soaring" melodic line carrying away into other, divine, realms, the middle part shows Li Yundi as a master pianist in terms of the deep spiritual scope of the whole Chopin's concept.

When listening to Li Yundi, Liszt's words are involuntarily recalled, "Can we ignore the Funeral March from his first sonata, which was instrumented and performed for the first time during the mourning ceremony at his funeral?! Indeed, no other sounds could be found to express that soul-rending emotion, those tears which must accompany to the last resting-place of one who so perfectly comprehended how great losses are mourned! ... There is a feeling that not the death of a single hero is mourned here... but the whole generation has fallen" [6,p.86-88].

The last part of the Sonata is, as Anton Rubinstein put it, "night vision over the coffins in the cemetery". It usually takes pianists 1.5-2 minutes to play this part. Li Yundi plays this part for 60 seconds. Very fast tempo, and unison sounding of the left and right hands create a sonic phantasmagoria. Here it is quite obvious, a tragic end to the life of a romantic hero.

Findings Results. We addressed to the most important musical-theoretical and aesthetic concept, which has its origin from the Latin word intono "loudly pronounce". We analyzed the work of two outstanding Chinese pianists - Fu Tsung and Li Yundi. Using their examples, we introduce the concept in which the problem of intonation of Slavic music is 
successfully solved by representatives of a different mentality, due to the strong professional base obtained during training, as well as to the special receptive qualities of musical talent, successfully developed in the process of concert activity of $\mathrm{Fu}$ Tsung and $\mathrm{Li}$ Yundi. In domestic and Chinese musicology, this problem has not received deep coverage yet. In the XXI century, Frederick Chopin's heritage is addressed by venerable pianists and students of educational institutions, music lovers and scientists. "Millions and millions of hearts are turned to Chopin; his art unites in one feeling the most sophisticated listener and the most demanding connoisseur. Chopin's international significance is in the fact that he is understandable and close to all countries and peoples, closely connected with his love for his people, for his homeland, without which his internationalism would be impossible and unthinkable" [7,p.46]. It is well known that the language of music is an international one. Chopin helps people of different countries and continents to understand each other without words, due to the language of music.

$$
\text { *** }
$$

1. Asafyev B.V. Musical Form as a Process. Leningrad: State Music Publishing House, 1963.

2. Vanslov V.V. The Concept of Intonation in Modern Musicology // Issues of Musicology. Part I, Moscow, 1953-1954.

3. Wang Yuhe. On Music and Musicians / Wang Yuhe - Guangdong, Guangdong Music Publishing House, 1997.

4. Kremlev Yu.A. Frederick Chopin. Essay on His Life and Works. Moscow: State Music Publishing House, 1960.

5. $\quad$ Li Yin. Chinese Piano Legend: Li Yundi // Li Yin - Gwangju: City of Flowers, 2007.

6. Liszt F. F. Chopin. Moscow: State Music Publishing House, 1956.

7. Neuhaus H. The poet of the piano // Soviet Music, 1946. № 9. P. 46.

8. Sokhor A.N. Intonation // Musical Encyclopedia in 6 vol.s. Ed. Keldysh Yu.V. Vol. 2. Moscow: Soviet Encyclopedia, 1974.

9. Fu Tsung. Fu Tsung is nearly seventy! / Fu Tsung - Tianjin, Academy of Social Sciences of Tianjin, 2004.

10. Shakhnazarova N.G. Prosodic "Dictionary" and the Problem of Ethnicity in Music. Moscow, 1961.

11. Shi Yawen, Samsonova T.P. Chinese pianists-performers of works by Frederick Chopin in the musical space of Eurasia in the aspect of prosodic sounding // Modern Science: Actual Problems of Theory and Practice. № 8. 2019 (August).

12. Chopin F. Complete works. Ed. I. Paderevsky. T.VI. Сонаты. Frederick Chopin Institute. Polskie wydawnictwo muzyczne. P.54-78.

13. URL.www.youtube.com/ Yundi Li Chopin’s Piano Sonata № 2 in B flat minor, Op. 35(Finerel March)/ Date of reference: 08.02.2019. 